JOURNAL

of Health Inequalities

\title{
Remembering Professor Jabłońska
}

\author{
Sławomir Majewski \\ Department of Dermatology and Venereology, Medical University of Warsaw, Poland
}

\begin{abstract}
ADDRESS FOR CORRESPONDENCE: Sławomir Majewski, Department of Dermatology and Venereology, Medical University of Warsaw, Poland, 61 Żwirki i Wigury Street, 02-091 Warsaw, e-mail: slawomir.majewski@wum.edu.pl
\end{abstract}

On May $8^{\text {th }} 2017$, Professor Stefania Jabłońska - an extraordinary personality, our great teacher and friend, passed away. It is difficult in just a few words to describe the Professor's stature and her contribution to world medicine and dermatology, but they are widely known. For us, her students, just as important is the enormous influence that her personality had on our professional and often private lives. The extraordinary intellectual adventure of working under Professor Stefania Jabłońska's direction, and my later collaboration with her, was for me and many of my colleagues our introduction to the great world of medicine. The Professor showed us what true science, as well as what honest and loyal scientific collaboration involves.

As early as 1972, she was the first in the world to formulate a hypothesis concerning the oncogenic action of the papillomavirus in patients with the rare genetic disease epidermodysplasia verruciformis (EV), in which papillary lesions transform into skin cancers. In collaboration with (her close friend) Professor Gérard Orth of the Pasteur Institute in Paris, she worked on the molecular characteristics of the first oncogenic EV-HPV viruses and showed that infection with these viruses does not cause skin cancer in healthy individuals of different genetic backgrounds. In this way, evidence was obtained showing that skin cancers can be genetically determined, as was later confirmed by detecting mutation of new genes (EVER) in patients with EV. For her work on EV, Professor Jabłońska, along with Professor Orth, received the very prestigious Koch Award, presented to them at the award ceremony by German President R. von Weizsäker (1985).

Another of Professor Jabłońska’s friends, Professor Steve Katz of the National Institutes of Health, wrote after her death that: "Professor Jabłońska was an inspiration to those who dedicated their lives to dermatology. For many years she opened doors for many young scientists from Europe and Poland, thus ensuring the world's knowledge was available to many" and added that "Her important and groundbreaking scientific achievements will constitute a living monument to her memory".

I remember, indeed many of us remember, that particular scientific atmosphere in the Professor's office, where we prepared dozens of scientific publications, on which we often worked into the small hours of the morning. But that was our passion, a passion that was instilled in us by the Professor. And THAT is what we will remember forever, that extraordinary gift, which we received from our Great Teacher. Dear Professor, thank you for that gift and for all that you taught us over so many years... You will remain in our hearts and minds forever!!!

\section{DICLOSURE}

Author reports no conflict of interest. 